\title{
Mechanical Properties of Concrete Incorporating Marble Powder as Partial Cement Replacement
}

\author{
Rashid Ali Kanhar ${ }^{1}$, Muhammad Jaffar Memon ${ }^{1, *}$, Abdul Razzaque Sandhu ${ }^{1}$, Ashfaque Ahmed Jhatial ${ }^{1}$, \\ Aamir Khan Mastoi ${ }^{2}$ \\ ${ }^{1}$ Department of Civil Engineering, Mehran University of Engineering and Technology, Shaheed Zulfiqar Ali Bhutto Campus, \\ Khairpur Mirs', Sindh, Pakistan. \\ ${ }^{2}$ Department of Civil Engineering, QUEST, Nawabshah, Pakistan. \\ ${ }^{*}$ Corresponding author: Jaffar.memon@muetkhp.edu.pk
}

\begin{abstract}
Pakistan is a country that has an abundance of quarry deposits. The marble and ceramics industry, such as the construction industry, plays a pivotal role in the development of a country by contributing to the Gross Domestic Product (GDP). However, the marble and ceramics industry also adversely contribute to the growing solid waste management issues in the country, as Marble powder (MP), which comes from the marble industry, causes not only constant environmental and waste management problems, but also health issues for the people associated with the marble industry and surrounding residents. A lot of research has been done to reuse this MP waste productively. Since it contains significant amount of Silica content, it could potentially be used to partially substitute cement content in the development of eco-friendly sustainable concrete. The substitution of cement has become necessary due to the carbon footprint associated with the production of cement. This research is aimed at producing M30 grade concrete in which cement content is partially replaced with $5 \%$ and $10 \% \mathrm{MP}$ and investigate its influence on the workability, compressive and flexural strength over time. It was found that MP could potentially be used to substitute cement content partially, thus contributing to sustainability in the construction industry, resolving the disposal of MP problems, and reducing cement dependency.
\end{abstract}

Keywords-Alternative binders, cement conservation, marble powder, supplementary cementitious materials, sustainable concrete, waste utilization

\section{Introduction}

$\mathrm{T}$ HE construction industry is a country's backbone as it contributes significantly to the country's socio-economic development [1]. Concrete is the most used construction material in the construction industry and is considered to be the second most consumed substance. This popularity of concrete is due to the durability, flexibility and locally available features. Different concrete types could be prepared for different applications, ranging from simply constructing a residential house to skyscrapers, bridges to dams, and nuclear plants to airports [2]. Concrete is an amalgamation of cement, aggregates, water and sometimes admixtures. With an increase in the ur-

ISSN: 2523-0379 (Online), ISSN: 1605-8607 (Print)

DOI: https://doi.org/10.52584/QRJ.1901.08

This is an open access article published by Quaid-e-Awam University of Engineering Science $\&$ Technology, Nawabshah, Pakistan under CC BY 4.0 International License. ban population, large-scale development and constructional activities have been ongoing worldwide. These constructional activities consume natural resources exponentially, while cement production contributes to approximately $10 \%$ of the total global carbon dioxide $\left(\mathrm{CO}_{2}\right)$ gas emissions [3], causing climate change. The decreasing natural resources and carbon footprint have been challenging for the construction industry [4]. Therefore, researchers have been continuously trying to find as many alternatives to the ingredients used in concrete production as possible. Though the cement dependency as the main binder will not be replaced totally, cement content partially substituted is also a significant gain, as any reduction in cement content will reduce the production of cement, thus reducing the $\mathrm{CO}_{2}$ gas emissions. Waste materials are potential materials which can be used as supplementary cementitious materials (SCMs). Various waste materials 
which are being produced in exponential amount, such as palm oil fuel ash [5][6][7][8], rice husk ash [9][10], eggshells [11][4][12][13][14], fly ash [15], wood waste ash [16] and granulated ground blast furnace slag [17][18] among others have been widely used as SCMs and successfully reducing the cement content. Pakistan is a booming developing country, where many waste materials are generated in abundance, and most of them are suitable SCMs. Pakistan has vast marble deposits and a vibrant marble and ceramics industry, contributing significantly to its economy [19]. However, the marble and ceramics industry produce several wastes; these can be powder, sludge and broken marbles of varying sizes. Marble Powder (MP) is a waste product generated in abundance, as marbles are being used for decorative purposes across the world [20]. A large quantity of waste is produced during manufacturing, polishing, and finishing stages of marble. It has been estimated that approximately $20 \%$ to $30 \%$ of a marble block becomes MP waste during marbles' cutting process [21]. In comparison, $50 \%$ of the marble blocks are wasted during the production process [22]. Furthermore, 90\% of the MP particles are below $200 \mu m$ [22]. Being fine causes severe health issues for the people associated with the marble industry and surrounding residents, as marble waste is usually dumped in open grounds. With the increase in marble activities, the generation of MP also increases, therefore, causing solid waste management issues. This increasing waste risks the environment. It pollutes the air, contaminates water and also occupies a large space.

The following research indicates that the incorporation of MP is possible in concrete production with cement and fine aggregate replacement. Memon et. al. [19] studied the influence of MP on concrete properties when used as fine aggregate substituting material. The fine aggregates were replaced from 0 to $100 \%$ with an increment of $25 \%$. It was found that the MP could potentially be used as fine aggregates without any loss in the strength of concrete. The ideal substitution of $50 \%$ sand with MP was found, resulting in an increase of $13.52 \%$ in compressive strength and a significant $35.54 \%$ in flexural strength compared to the control concrete.

Quanth et. al. [23] conducted an experimental work, in which MP at different percentage replacement has replaced sand and cement. Sand has been replaced from 0 to $100 \%$, while cement has been replaced at $0 \%, 5 \%$ and $10 \%$ by MP. To check the use of MP, mechanical and durability tests have been performed. The tests have been performed on M30 concrete. It has been found in their study that concrete mixes having $25 \%$ fine aggregates and $10 \%$ cement replaced by MP gives compressive and splitting tensile strengths nearly the same results as the normal mix.

Kalchuri et. al. [24] conducted an experimental study, in which sand has been replaced by marble slurry in four different proportions of $10 \%, 20 \%, 30 \%$ and $40 \%$. To check the sustainability of MP as a fine aggregate replacement, the compressive strength was conducted after 7-, 28- and 90 days of curing. The results showed that an increase in the compressive strength could be achieved with the utilization of MP. In a different study, 0 to $20 \%$ cement content was replaced with marble dust powder [25]. The mechanical strengths were determined after the concrete was cured for 7 - and 28 days to assess marble dust powder's suitability. It was observed that the compressive strength of concrete increased up to $10 \%$ and flexural and split tensile strength increased up to $15 \%$. The experimental study concluded that marble dust powder could save the environment if partially replaced.

Mahadevi et. al. [26] conducted an experimental work on M25 grade concrete by substituting cement content with 20 to $30 \%$ MP. The incorporation of MP resulted in the reduction of workability, such that the higher content of MP further decreased the flowability. Furthermore, the concrete incorporating MP showed an increase in tensile and flexural strength compared to the control sample without any MP; however, the higher content of MP resulted in a reduction in concrete compressive strength.

Boukhelkhal et. al. [27] studied the influence of MP on self-compacting concrete (SCC) when utilized as SCMs. The study's findings showed that the freshstate properties of SCC are enhanced by incorporating MP; however, MP reduced the mechanical capabilities and UPV of concrete in hardened-state. Despite the reduction, it was concluded that the replacement of cement by MP in SCC production could be economical as a higher volume of cement is used in SCC compared to conventional concrete.

Based upon the literature review, it can be concluded that MP could potentially be used as both cement and fine aggregates replacement; however, there is still a significant gap in the understanding of the effect of MP on concrete if used as partial cement replacement especially in higher grade concrete, which is used for structural applications. Furthermore, to reduce the quantity of MP, to reduce the environmental issues associated with open landfill dumping of such fine powders waste, and simultaneously reduce the cement content in concrete production, this experimental work was conducted. This experimental work's scope was to determine the effect of partial replacement of cement with $5 \%$ and $10 \%$ MP (by weight of 
total binder) and compare it with the conventional concrete's compressive strength.

\section{Research Methodology}

The methodology of this research is presented in the following sections.

\subsection{Materials}

To study the influence of partially substituting cement content with MP on concrete strength, an M30 grade concrete was cast. Lucky Cement, which is CEM I and adheres to EN 197-1:2011 [28] was used, while locally available fine and coarse aggregates were used. The fine aggregates and coarse aggregates once sieved through $4.75 \mathrm{~mm}$ and $20 \mathrm{~mm}$ sieves were oven-dried to remove any moisture and stored in air-tight plastic bags until the casting day. The mix proportions are shown in Table 1. The properties of binder materials are shown in Table 2.

\subsection{Experimental Procedure}

The dry raw materials were placed in the rotary mixer and allowed to mix, and the water was gradually added. The mix's slump was determined as per ASTM C143 [29] and afterwards steel moulds were filled with wet mixture and left for 1 day before demoulding the samples and placing them in the water tank curing. To determine the compressive strength of concrete, a total of 9 cubes ( 3 cubes were prepared for 7-, 28and 90 days curing) of $15 \times 15 \times 15 \mathrm{~cm}$ dimensions were prepared and tested according to BS EN 12390-3 [30]. While for flexural strength, three prisms of 50x10x10 $\mathrm{cm}$ were cast for each curing age (28 and 90 days) and tested according to BS EN 12390-5 [31].

\section{Results \& Discussion}

The following sections present the results and detailed discussion.

\subsection{Workability}

The workability of concrete mixes was recorded using a slump cone is illustrated in Figure 1. It can be seen that the workability increases with an increase in MP content. This could be due to the difference in both the binder materials' specific gravity, which allows the MP to act as a low-level superplasticizer for the mix.

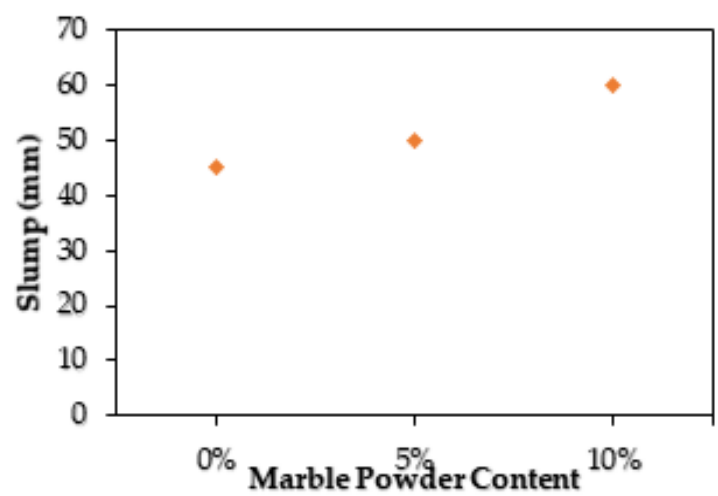

Fig. 1: Workability of concrete incorporating various marble powder content

\subsection{Compressive Strength}

The average compressive strength of concrete is shown in Figure 2 and Table 3. It can be observed that the compressive strength of concrete incorporating MP was lower than the controlled concrete without any addition of MP at an early age; however, the concrete incorporating MP gained significant strength at 90 days. It exhibited an increase of $16.65 \%$ and $17.27 \%$ with the incorporation of $5 \%$ and $10 \% \mathrm{MP}$, respectively, compared to the control sample. The enhancement in strength is the result of the reaction between the water and cement particles. However, MP is known to be inert, and as such does not hydrate like cement particles, therefore, higher content of MP could adversely influence the compressive strength of concrete. Although MP does not possess any pozzolanic property, it can enhance the properties if a certain MP content is used as SCM in concrete. The enhancement has been attributed to the water absorption by MP [32].

\subsection{Flexural Strength}

The flexural strength of concrete incorporating MP is shown in Figure 3 and Table 4. The behaviour of concrete under flexural exhibited a similar trend as compressive strength. At an early age, the strength is slightly lower for concrete incorporating MP, but with the increase in the curing duration, the flexural strength of concrete incorporating MP increased. The reason attributed to the increase in the compressive strength of concrete incorporating MP is also valid for the increase in flexural strength of concrete incorporating MP [32].

\section{Recommendations}

It is recommended that the cement content be further replaced with marble powder, and since it contains 


\begin{tabular}{|c|c|c|c|c|c|c|c|c|}
\hline \multirow{3}{*}{ Mix Name } & \multicolumn{2}{|c|}{ Binder Content } & \multicolumn{6}{|c|}{ Amount in $\mathrm{kg}$ to produce $1 \mathrm{~m} 3$ of concrete } \\
\hline & \multirow{2}{*}{ Cement } & \multirow{2}{*}{ MP } & \multirow{2}{*}{ Cement } & \multirow{2}{*}{ MP } & \multicolumn{3}{|c|}{ Aggregates (mm) } & \multirow{2}{*}{ Water } \\
\hline & & & & & $<4.75$ & $4.75-10$ & $10-20$ & \\
\hline M1 & $100 \%$ & $0 \%$ & 410.39 & 0 & 605.58 & 741.47 & 494.31 & 196.57 \\
\hline M2 & $95 \%$ & $5 \%$ & 389.87 & 20.52 & 605.58 & 741.47 & 494.31 & 196.57 \\
\hline M3 & $90 \%$ & $10 \%$ & 369.35 & 41.04 & 605.58 & 741.47 & 494.31 & 196.57 \\
\hline
\end{tabular}

TABLE 1: Mix proportions and quantity to produce $1 \mathrm{~m}^{3}$ of concrete

\begin{tabular}{|l|l|l|l|l|l|l|l|l|}
\hline Oxides (\%) & CaO & SiO2 & Al2O3 & Fe2O3 & MgO & SO3 & LOI & Specific Gravity \\
\hline OPC & 60.82 & 20.05 & 5.02 & 3.35 & 11.94 & 2.18 & 1.67 & 3.16 \\
\hline MP & 53.79 & 0.67 & 0.49 & 0.2 & 0.71 & 0.09 & 43.72 & 2.39 \\
\hline
\end{tabular}

TABLE 2: Chemical composition of OPC and MP

\begin{tabular}{|l|l|l|l|l|l|l|l|}
\hline \multirow{2}{*}{ Mix } & \multirow{2}{*}{ MP Content } & \multicolumn{2}{|l|}{ 7 Days } & 28 Days & \multicolumn{2}{l|}{ 90 Days } \\
\cline { 3 - 8 } & $\begin{array}{l}\text { Average } \\
\text { (MPa) }\end{array}$ & $\begin{array}{l}\text { Difference w.r.t. } \\
\text { M1 (\%) }\end{array}$ & $\begin{array}{l}\text { Average } \\
\text { (MPa) }\end{array}$ & $\begin{array}{l}\text { Difference w.r.t. } \\
\text { M1 (\%) }\end{array}$ & $\begin{array}{l}\text { Average } \\
\text { (MPa) }\end{array}$ & $\begin{array}{l}\text { Difference w.r.t. } \\
\text { M1 (\%) }\end{array}$ \\
\hline M1 & $0 \%$ & 18.25 & - & 25.25 & - & 29.19 & - \\
\hline M2 & $5 \%$ & 16.84 & -7.73 & 24.52 & -2.89 & 34.05 & +16.65 \\
\hline M3 & $10 \%$ & 17.1 & -6.30 & 21.74 & -13.90 & 34.23 & +17.27 \\
\hline
\end{tabular}

TABLE 3: Compressive strength of M30 grade concrete with and without marble powder

\begin{tabular}{|l|l|l|l|l|l|}
\hline \multirow{2}{*}{ Mix } & \multirow{2}{*}{ MP Content } & $\begin{array}{l}\text { 28 Days } \\
\text { Average } \\
\text { (MPa) }\end{array}$ & $\begin{array}{l}\text { Difference w.r.t. } \\
\text { M1 (\%) }\end{array}$ & $\begin{array}{l}\text { 90 Days } \\
\text { Average } \\
\text { (MPa) }\end{array}$ & $\begin{array}{l}\text { Difference w.r.t. } \\
\text { M1 (\%) }\end{array}$ \\
\hline M1 & $0 \%$ & 5.71 & - & 6.14 & - \\
\hline M2 & $5 \%$ & 5.76 & +0.88 & 6.91 & +12.54 \\
\hline M3 & $10 \%$ & 5.06 & -11.38 & 6.21 & +1.14 \\
\hline
\end{tabular}

TABLE 4: Flexural strength of M30 grade concrete with and without marble powder

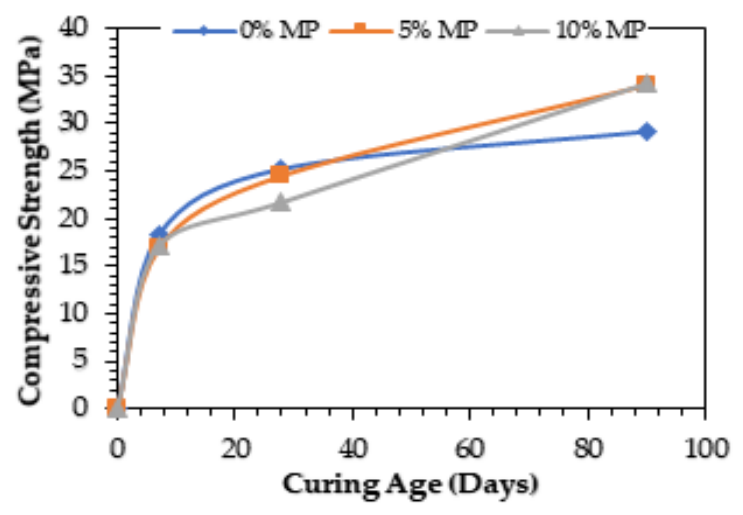

Fig. 2: Influence of marble powder on the compressive strength of concrete over curing age

significant amount of $\mathrm{CaO}$, it could be used with other waste materials which have pozzolanic property, as during the pozzolanic reaction, $\mathrm{CaO}$ is consumed, and additional C-S-H gels are developed.

\section{Conclusion}

This study aimed to substitute partially cement content with marble powder to reduce the cement content

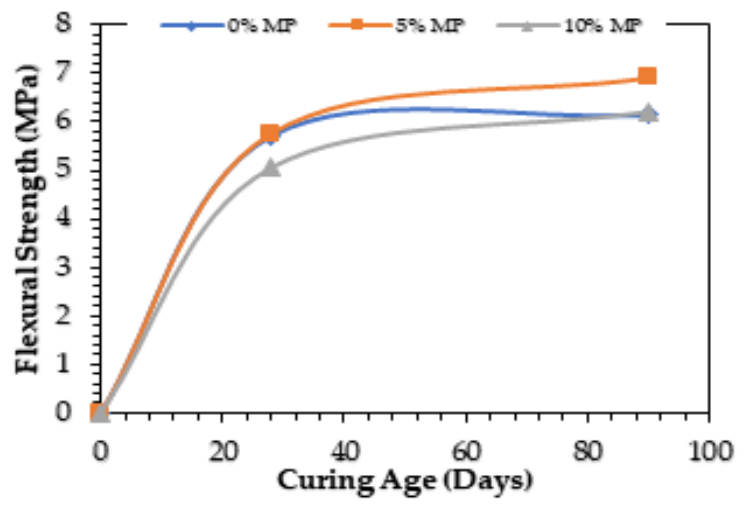

Fig. 3: Influence of marble powder on the flexural strength of concrete over curing age

required in the production of concrete, thus reducing its dependency and solving the issue of increase in marble powder waste being generated by the marble and ceramics industry. Based on the results, following conclusions can be drawn.

- The addition of marble powder, acting as a lowlevel superplasticizer, increases the workability with the increase in marble powder content.

- Though the compressive strength of concrete in- 
corporating marble powder was comparatively lower than the control sample at an early stage. However, at 90 days, the difference reduced and the compressive strength of concrete incorporating marble powder significantly increased compared to the control sample.

- A similar trend was observed for the flexural strength of concrete, with the increase inmarble powder, the flexural strength increased significantly.

- Partial substitution of cement content with marble powder is possible without loss of strength. This could contribute to reducing the dependency on cement as well as solving the disposal of Marble Powder.

\section{Acknowledgement}

The support provided by the staff of the Department of Civil Engineering, Mehran University of Engineering and Technology, Shaheed Zulfiqar Ali Bhutto Campus, Khairpur during this experimental work is highly appreciated.

\section{References}

[1] Sohu, S., Ullah, K., Jhatial, A. A., Jaffar, M., and Lakhiar, M. T., "Factors adversely affecting quality in highway projects of Pakistan," International Journal of Advanced and Applied Sciences, vol. 5, no. 10, pp. 62-66, 2018.

[2] Jhatial, A. A., Mastoi, A. K., Siyal, Z. A., Rind, T. A., and Memon, I. A., "Influence of Long Polypropylene Fibre on the Properties of Concrete," Quaid-E-Awam University Research Journal of Engineering, Science \& Technology, Nawabshah, vol. 18, no. 2, pp. 38-43, 2020.

[3] Suhendro, B., "Toward Green Concrete for Better Sustainable Environment," Procedia Engineering, vol. 95, pp. 305-320, 2014.

[4] Jhatial, A. A., Goh, W. I., Mo, K. H., Sohu, S., and Bhatti, I. A., "Green and Sustainable Concrete - The Potential Utilization of Rice Husk Ash and Egg Shells," Civil Engineering Journal, vol. 5, no. 1, p. 74, 2019.

[5] Jhatial, A. A., Goh, W. I., Sohu, S., Mangi, S. A., and Mastoi, A. K., "Preliminary Investigation of Thermal Behavior of Lightweight Foamed Concrete Incorporating Palm Oil Fuel Ash and Eggshell Powder," Periodica Polytechnica Civil Engineering, vol. 65, no. 1, pp. 168-180, 2021.

[6] Rahman, A. F., Goh, W. I., Mohamad, N., Kamarudin, M. S., and Jhatial, A. A., "Numerical analysis and experimental validation of reinforced foamed concrete beam containing partial cement replacement," Case Studies in Construction Materials, vol. 11, 2019.

[7] Rahman, A. F., Goh, W. I., and Jhatial, A. A., "Flexural study of reinforced foamed concrete beam containing palm oil fuel ash (POFA) and eggshell powder (ESP) as partial cement replacement," International Journal of Sustainable Construction Engineering and Technology, vol. 10, no. 1, 2019 .
[8] Jhatial, A. A., Goh, W. I., Rind, T. A., and Kumar, A., "Thermal Performance Simulation of Eco-Friendly Lightweight Foamed Concrete Incorporating Palm Oil Fuel ash and Eggshell Powder Using ABAQUS," Silicon, pp. 1-20, 2021.

[9] Phulpoto, K. B., Jhatial, A. A., Memon, M. J., Sandhu, A. R., and Sohu, S., "Effect of Polypropylene Fibre on the Strength of Concrete Incorporating Rice Husk Ash," Journal of Applied Engineering Sciences, vol. 10, no. 1, pp. 69-71, 2020.

[10] Lakhiar, M. T., Ali, A., Ying, K. S., and Lakhiar, M. T., "Computational and Experimental Analysis of Reinforced Aerated Concrete Beam Concrete Containing Rice Husk Ash," Preprints, vol. 2020070510, 2020.

[11] Tiong, H. Y., Lim, S. K., Lee, Y. L., and Lim, J. H., "Engineering Properties of $1200 \mathrm{~kg} / \mathrm{m} 3$ Lightweight Foamed Concrete with Egg Shell Powder as Partial Replacement Material of Cement," E3S Web of Conferences, vol. 65, p. 02010, 2018.

[12] Ujin, F., Ali, K. S., and Hanur Harith, Z. Y., "The Effect of Eggshells Ash on the Compressive Strength of Concrete," Key Engineering Materials, vol. 728, pp. 402-407, 2017.

[13] Owuamanam, S. and Cree, D., "Progress of Bio-Calcium Carbonate Waste Eggshell and Seashell Fillers in Polymer Composites: A Review," Journal of Composites Science, vol. 4, no. 2 , p. 70, 2020.

[14] Jhatial, A. A., Sohu, S., Memon, M. J., Bhatti, N., and Memon, D., "Eggshell powder as partial cement replacement and its effect on the workability and compressive strength of concrete," International Journal of ADVANCED AND APPLIED SCIENCES, vol. 6, no. 9, pp. 71-75, 2019.

[15] Phul, A. A., Memon, M. J., Shah, S. N. R., and Sandhu, A. R., "GGBS And Fly Ash Effects on Compressive Strength by Partial Replacement of Cement Concrete," Civil Engineering Journal, vol. 5, no. 4, pp. 913-921, 2019.

[16] Raza, M. S., Rai, K., Kumar, D., and Ali, M., "Experimental Study of Physical, Fresh-State and Strength Parameters of Concrete incorporating Wood Waste Ash as a Cementitious Material," Journal of Materials and Engineering Structures, vol. 7, no. 2, pp. 267-276, 2020.

[17] Sandhu, A. R., Rind, T. A., Kalhoro, S. A., Lohano, R., and Laghari, F. H., "Effect on the Compressive Strength of Mortars Using Ground Granulated Blast Furnace Slag as a Partial Replacement of Cement," Journal of Applied Engineering Sciences, vol. 9, no. 2, pp. 183-186, 2019.

[18] Rind, T. A., Karira, H., Mirani, S. A., and Mari, A. K., "Influence of Ground Granulated Blast Furnace Slag on the Index, Compaction Parameters and Mechanical Strength of Khairpur Mir's Natural Soil," Journal of Applied Engineering Sciences, vol. 10, no. 1, pp. 83-88, 2020.

[19] Memon, M., Jhatial, A., Rid, Z., Rind, T., and Sandhu, A., "Marble Powder As Fine Aggregates in Concrete," Engineering, Technology \& Applied Science Research, vol. 9, no. 3, pp. 4105-4107, 2019.

[20] Alyousef, R., Benjeddou, O., Soussi, C., Khadimallah, M. A., and Mustafa Mohamed, A., "Effects of Incorporation of Marble Powder Obtained by Recycling Waste Sludge and Limestone Powder on Rheology, Compressive Strength, and Durability of Self-Compacting Concrete," Advances in Materials Science and Engineering, vol. 2019, pp. 1-15, 2019.

[21] Ulubeyli, G. C. and Artir, R., "Properties of Hardened Concrete Produced by Waste Marble Powder," Procedia Social and Behavioral Sciences, vol. 195, pp. 2181-2190, Jul. 2015 . 
[22] Khaliq, S. U., Khan, S., Alam, B., Bilal, F., Zeb, M., and Akbar, F., "Marble Powder's Effect on Permeability and Mechanical Properties of Concrete," International Journal of Civil, Environmental, Structural, Construction and Architectural Engineering, vol. 10, no. 4, pp. 509-514, 2016.

[23] Quanth, K. K. and Karla, T., "Experimental utilization of marble dust powder as partial replacement of cement and fine aggregates in concrete," International Journal of Engineering, Pure and Applied Sciences, vol. 3, no. 1, pp. 7-11, 2018.

[24] Singh Kalchuri, B., Chandak, R., and Yadav, R. K., "Study On Concrete Using Marble Powder Waste As Partial Replacement Of Sand," Journal of Engineering Research and Applications www.ijera.com, vol. 5, no. 4, pp. 87-89, 2015.

[25] Kumar, R. and Kumar, S. K., "Partial Replacement of Cement with Marble Dust Powder," Int. Journal of Engineering Research and Applications, vol. 5, no. 8, pp. 106-114, 2015.

[26] Mahadevi, R., Sam, B. M., Ilavarasan, K., Kumar, M. P., and Ramachandran, M., "Experimental Investigation on Partial Replacement of Cement By Marble Powder and Quarry Dust," International Research Journal of Engineering and Technology (IRJET), vol. 04, no. 04, pp. 353-356, 2017.

[27] Boukhelkhal, A., Azzouz, L., Belaïdi, A. S. E., and Benabed, B., "Effects of marble powder as a partial replacement of cement on some engineering properties of self-compacting concrete," Journal of Adhesion Science and Technology, vol. 30, no. 22, pp. 2405-2419, 2016.

[28] BS EN 197-1:2011, "Cement. Composition, specifications and conformity criteria for common cements," 2011.

[29] ASTM C143 / C143M-20, "Standard Test Method for Slump of Hydraulic-Cement Concrete," 2020.

[30] BS EN 12390-3, "Testing hardened concrete. Compressive strength of test specimens," 2019.

[31] BS EN 12390-5, "Testing hardened concrete. Flexural strength of test specimens," British Standards Institution, London, 2019.

[32] Yamanel, K., Durak, U., İlkentapa, S., Atabey, İ. İ., Karahan, O., and Atiş, C. D., "Influence of waste marble powder as a replacement of cement on the properties of mortar," Revista de la construcción, vol. 18, no. 2, pp. 290-300, 2019. 